\title{
Neden antropoloji? Aktivist antropoloji üzerine bir değerlendirme
}

\author{
Semra Özlem Dişli ${ }^{i^{*}}$ ○ \\ 'Dr. | Mardin Artuklu Üniversitesi, Edebiyat Fakültesi, Antropoloji Bölümü, Mardin - Türkiye
}

\section{Öz}

2020 yllının başından itibaren tüm dünyayı etkisi altına alan COVID-19 salgını ve salgın yöntemi ekolojik yıkım, iklim krizi, yoksulluk ile yerleşik eşitsizlik gibi mevcut birçok sorunu daha da görünür hale getirdi. $\mathrm{Bu}$ yazı da antropolojinin bu mevcut sorunların çözümüne nasıl katkı sağlayabileceği üzerine düşünerek, aktivist antropoloji yaklaşımını konu edinmektedir. Bu bağlamda yazı konuyu üç aşamada ele almaktadır. İlk olarak disiplinin sınırlarına ilişkin genel bir değerlendirme yapılmaktadır. $\mathrm{Bu}$ değerlendirme aktivizm ile antropoloji arasındaki keskin ayrımdan hareket etmektedir. İkinci olarak ise toplumsal sorunların çözümüne yönelik antropoloji yaklaşımını ifade eden uygulamalı antropoloji yaklaşımı ele alınmaktadır. Uygulamalı antropolojinin ele alınmasındaki amaç, aralarındaki benzerlik ve farklılıkları yoluyla aktivist antropolojinin analizine zemin hazırlamaktadır. Nihayet, aktivist antropoloji incelenerek antropolojiyi kamusal bir ses ve sorumluluğa, dahası bir mücadele alanı haline dönüștürme imkânın ortaya konması hedeflenmektedir.

Anahtar sözcükler: Antropoloji, etnografi, uygulamalı antropoloji, aktivist antropoloji

\section{Giriş}

Benimsediği etnografik yöntem ile antropolojinin sosyal disiplinler içinde ayrıcalıklı bir yeri olduğu sıklıkla dile getirilir. Her ne kadar günümüzde başka disiplinlerin de başvurduğu bir yöntem olsa da etnografi hala araştırma konusuna kendine özgü yaklaşımını belirterek antropolojiyi tanımlamada kullanılan temel araçtır. Etnografik yöntemi bu denli önemli kılan ise antropolojinin kültürel alanları anlama ve aktarma çabasinda içeriden bakma ilkesini esas alarak bilgi üretmeye yönelik olmasıdır. Bu yazı, içeriden bakma ilkesi ile antropolojiyi ayrıca, eşitsizliğin ve adaletsizliğin gündelik deneyimin bir parçası olageldiği dünyada toplumsal sorunların çözümünde de etkili olabilecek öncelikli disiplinlerden biri olarak ele alıyor. Yazının odağ1 doğrudan antropolojik bilginin üretilmesine ilișkin yöntemsel bir tartışma değildir. Bunun yerine yaz1 "neden antropoloji” sorusu üzerine düşünüyor ve
Why anthropology? An evaluation on activist anthropology

\section{Abstract}

Since the beginning of 2020, COVID-19 pandemic has been affecting the whole world. The pandemic and its governance have been creating many problems such as ecological devastation, climate crisis, poverty and entrenched inequality more visible. Thinking about the question of how anthropology could contribute to the solution of these current problems, this paper scrutinizes activist anthropology. In this context this paper proceeds through three broad topics. In the first topic, a general evaluation is made on the limit of anthropology. This evaluation depends upon a strong distinction between anthropology and activism. Secondly, applied anthropology as a social problemsolving-oriented anthropological approach is discussed. The objective of discussing applied anthropology is to provide a basis for analyzing activist anthropology through similarities and differences between them. Finally, activist anthropology is examined. By this way, this paper aims at revealing the opportunity to turn anthropology into a public voice and responsibility, moreover a into a field of struggle.

Key words: Anthropology, ethnography, applied anthropology, activist anthropology

disiplindeki bir dizi tartışmayı da takip ederek, bu soruya aktivist antropoloji ile cevap aryor. Antropolojiyi bir mücadele alanı olarak kabul eden aktivist antropoloji yaklaşımı, dünyayı daha iyiye doğru değiştirme saikiyle antropolojik bilginin üretilip kullanılmasını temel alır. Bu bağlamda aktivist antropoloji yaklaşımını konu edinen bu yazı üç bölümden oluşmaktadır. Yazıya temel bir ayrımın ele alınması ile başlanacaktır. Disiplin tarihinde çok eskilere dek takip etmenin mümkün olduğu bu ayrım antropoloji ile aktivizm arasındadır. Yazının bu ilk bölümünde günümüzde de antropolojinin standartlarından biri olarak görülen antropoloji ile aktivizm arasındaki ayrıma dair genel bir değerlendirme ortaya konacaktır. Toplumsal sorunların çözümünde etkili olmayı hedefleyen araştırma pratiklerinin tartışılmasına odaklanan diğer iki bölüm ise tarihsel bir dizge izlenerek ele alınmaktadır. Konunun tarihsel bir dizge içinden ele alınması bir yandan 
toplumsal-kuramsal dönüşümleri takip etmeyi diğer yandan da yazının odağı olan aktivist antropolojinin bunlarla ilgisinde hem ortaya çıkma koşullarını hem de özgünlüğünü açı̆̆a çıkarması açısından verimli bir çerçeve sunar. Toplumsal sorunların çözümünde etkili olmayı hedefleyen antropolojik bir yaklaşım dendiğinde de akla ilk gelen nerdeyse disiplinin kendisi kadar eski bir tarihe sahip olan uygulamalı antropoloji olacaktır. Hem bu açıdan hem de farklılıkları yoluyla aktivist antropolojiyi analiz etmekte iyi bir aracı olmasi ile yazı kapsaminda uygulamalı antropolojinin ele alınması zorunlu bir adımdır. Yazının ikinci bölümü de uygulamalı antropoloji yaklaşımına odaklanmaktadır. Tarihsel dizgeyi izlemeye devam ederek üçüncü ve son bölüm ise, disiplini mücadele alanının bir parçası olarak gören aktivist antropolojinin tartışılmasına ayrılmıştır.

\section{Aktivizm ile antropoloji ayrımına kısa bir bakış}

Kültürlerin Yorumlanması kitabinda Geertz (2010, s. 47) antropolojinin "asli görevi[nin] bizim en derin sorularımıza yanıt vermek değil, başka vadilerde başka koyunları güdenlerin verdikleri yanıtlara erişmemizi sağlamak ve böylece bu yanıtları insanın neler söylediğine ilişkin sonradan danışılabilir kayıtlara eklemek" olduğunu söyler. Yorumcu antropolojinin dayandığı bilgisel zeminden ayrı düşünülemeyecek bu ifade ile Geertz, bilginin kendi kültürel bağlamı içinde yakalanabileceğini vurgularken, antropolojinin yerel bilgileri derleyen bir başvuru kaynağı olma görevini üstlendiğini de dile getirir. Bu kaynağın nasıl, daha açık bir ifadeyle hangi amaçla kullanılacağının ise belirsiz bırakıldığ1 söylenebilir. Geertz’in alan çalışması yürüttüğü dönemde Endonezya'da yüz binlerce kişinin öldürüldüğü "19651966 Endonezya Katliamları” olarak bilinen olaylar yaşanmaktaydı. Geertz bu yaşananları görmezden gelir; ne yayınlarında ne de konuşmalarında bunlara yer verir (Ortner, 1999, s. 4; Schefer-Hughes ve Bourgois, 2004, s. 6-7). Bunun nedeni sorulduğunda, ScheferHughes ve Bourgois'nın (2004, s. 7) aktardıkları üzere Geertz'in cevabı hak savunuculuğu üreterek dikkatleri teorik tartışmalardan başka bir yöne çekmek istemediği olur. Geertz’in bu cevabı ile birlikte düşünüldüğünde antropolojinin derlediği bilginin hangi amaçla kullanılacağ1 da netliğe kavuşur. Buradan hareketle antropolojik bilginin yalnızca teorik tartışmalar üretmek üzere kullanılacağı sonucuna varmak pek de zor değildir. Çok geçmeden Geertz hem tanık olduğu şiddeti hem de genel olarak iktidar ilişkilerini görmezden geldiği için eleştirilecektir. Sadece Geertz değil, 1960 ve 1970’ler ile birlikte ondan önceki antropologlar da -örneğin Malinowski-araştırmasının baştan sona yapısını etkileyen kolonyal iktidarı sorun etmemesi, Evans-Pritchard ise kolonyal yönetiminin Nuerlere karşı yürüttüğü savaşa dair söz söylememesi ile eleştirilerin hedefinde olacaktır
(Sthauder, 1974, s. 41-42; Asad, 2008, s. 16-19). Yazının devamında yeniden değinilecek bu eleştirilere rağmen Geertz örneğinden hareketle antropolojiye egemen olan temel bir ayrım ortaya konabilir. Buna göre "hak savunuculuğu" antropoloji alanının dışına itilir. Bu ayrim sadece hak savunuculuğunun antropolojiden dişlanması ile sinırlı değildir. Daha genel olarak, hak savunuculuğunu da içine alan aktivizm antropolojinin dişında bırakılır. Aktivizm ile kast edilenler çok çeşitli ${ }^{1}$ olsa da çalışmada terim, mevcut toplumsal sorunlar karşısında pratik sonuçlar elde etmeye yönelik politik bir mücadelenin içerisinde ve bunun gereği politik anlamda bir taraf olup bu konumdan hareketle bilgi ve söylem üretme anlamında kullanılmaktadır. Aktivizm bir yanda, antropoloji ise diğer yanda yer alır ve bu ikisi keskin bir biçimde birbirinden ayrilır.

Peki, antropoloji ve aktivizm arasındaki ayrımın anlam ve önemi nedir? $\mathrm{Bu}$ ayrim antropolog ile araştırma özneleri arasındaki ilişkinin nasıl olması gerektiği, bu araştırma ilişkisi aracılığıyla üretilen bilginin neleri içerip içermeyeceği, bu bilginin nasıl ifade edilmesi gerektiği, hangi amaçla ve kimlerle paylaşılacağı gibi bir araştırmanın başından sonuna dek etkili olan meselelerinde belirleyici rol oynar. Bunu yaparken de antropolojinin sinırlarını belirler, yani bu ayrımın bizzat kendisi antropolojinin normlarından biri olarak karşımıza çıkar. Antropolog ile araştırma özneleri arasındaki ilişki politik bir mücadele ekseninde kurulan işbirliğinden, "yoldaşliktan" (Scheper-Hughes, 1995, s. 411, 419) ayrı tutulur. Üretilen bilgi de bu politik ilişkilenmenin dışarıda bırakıldığ1 araştırma ilişkisi ile kaçınılmaz olarak örtüşür. Buradaki eğilim, Wacquant'in (2014, s. 37) ifadeleriyle "dünyayı pratik çözümler gerektiren somut sorunlar gibi algilamaktan çok yorum bekleyen bir işaret bütünü gibi” algılama yönündedir. Bilginin nasıl ifade edileceği; kime neyi nasıl söylediğimiz meselesinde ise kamusal bir sorumluluktan ziyade akademiye olan sorumluluk esastır ${ }^{2}$ ve böylece antropolojik bilgi kapalı bir çevrede, akademi içinde dolaşır durur (ScheperHughes, 2009, s. 2; Eriksen, 2015, s. 264). Isşte aktivist antropoloji, disiplinin normlarından biri olan bu ayrımı yapıbozuma tabi tutarak, mücadele alanının bir parçası

\footnotetext{
${ }^{1}$ Bununla ilgili genel bir değerlendirme için bknz: Bora, T. (2020), Aktivizm. Birikim. https://birikimdergisi.com/haftalik/10371/ aktivizm (Erisim tarihi: 02.12.2020)

22017 yilinda doktora tez izleme komitesi toplantısindan sonra komite üyelerinden bir hoca ile tezim hakkında konuşmaya devam etmiştik. Bu konuşma sırasında, tezimde bazı konuları ele almayacağımı çünkü birlikte çalıştığım kişilerin benden istedikleri şeylerden birinin de bu olduğunu söyledim. Bunun üzerine hocam, "senin asıl sorumluluğun antropolojiye" demişti. "Neden antropoloji” sorusu üzerine düşünmeye başlamamda bu olayın oldukça etkili olduğunu belirtmek isterim.
} 
olarak gördüğü antropolojiyi kamusal ses ve sorumluluğa dönüştürme imkânı sağlar.

Aktivist antropoloji bu imkân ve çabanın tartışıldığ 1 antropoloji yaklaşımını işaret eden yegâne terim değildir. Örneğin uygulamalı antropoloji, kamusal antropoloji, ilişkilenen antropoloji ${ }^{3}$, ortak çalışmaya dayalı antropoloji, eylem antropolojisi, pratik antropoloji, militan antropoloji benzer tartsşmalarda yer alan diğer terimlerdir. $\mathrm{Bu}$ terimler aracillğıyla isimlendirilen antropolojik yaklaşımlar arasında farkl1lıklar olduğu ileri sürülebilir. Ancak farkl111klarından daha önemli bir biçimde bu yaklaşımların hepsi toplumsal sorunların çözümünde etkili olma hedefi taşır (Kirsh, 2010, s. 70; Lamphere, 2015, s. 163). Bu yaz1 kapsaminda anilan bu yaklaşımlar arasındaki farklılıklardan ziyade üzerinde durulması gereken bir başka nokta vardır. Militan antropoloji, ilişkilenen antropoloji, eylem antropolojisi gibi terimlerin antropolojinin kavramsal ajandasina girmesi yeni saylabilecekken, yukarida sıralanan bu terimlerden uygulamalı antropoloji neredeyse disiplinin kendisi kadar eskidir ${ }^{4}$. Üstelik uygulamalı antropolojinin, oldukça eskilere giden tarihiyle bağlantılı bir biçimde, toplumsal sorunların çözümüne yönelik pratik sonuçlar elde etmeyi hedefleyen yaklaşımların tümünü içinde barındıran bir çatı kavram olarak da kullanıldığını görmek mümkündür. Tek başına bu yönü bile uygulamalı antropolojiye daha yakın bakmayı gerektirir. Bunun yanı sıra, gelişimi ile birlikte incelendiğinde uygulamalı antropoloji ayrıca uygulamalı araştırmacılık, iktidar, toplumsal sorunlar ve çözümü arasındaki ilişkiler üzerine düşünmek, bunlarla ilgisinde aktivist antropolojiyi ele almak için oldukça verimli bir zemin sunar.

\section{Toplumsal sorunların çözümüne çalışmak: Uygulamalı antropoloji}

Daha önce uygulamalı antropolojinin neredeyse disiplinin kendisi kadar eski olduğu ifade edilmişti. Uygulamalı antropolojiyi gelişimiyle birlikte ele alırken,

\footnotetext{
${ }^{3}$ İlişkilenen antropoloji, engaged anthropology teriminin karş1lı̆̆1 olarak kullanılmaktadır. Bu terimin Türkçe karşılığı, Funda Şenol Cantek ve Besim Can Zirh'ın (2014) "Bir Semt Etnografisine Doğru: Cebeci'ye Bakmak" adlı yazılarında olduğu şekliyle kullanıldı.

4 Uygulamalı antropolojinin ele alındığı kimi çalışmalarda, bu antropolojik yaklaşımın tarihi "disiplin öncesi dönem"e (Akgül, 2013, s. 67) dek takip edilir. Bu çalışmada ise uygulamalı antropoloji, antropolojinin akademik bir disiplin haline gelmesi ile birlikte alındı. Antropolojinin akademik bir disiplin haline gelmesinin önemi, araştırma alanına dair daha dengeli ve sistematik bir yaklaşımın kurulmasındadır. Böyle bir yaklaşımın kurulmadı̆̆ı disiplin öncesi dönemler dışarıda bırakıldı. Ayrıca araştırmanın temel meselesi aktivist antropoloji olduğundan sinırlandırmaya gitmek de kaçınılmazdı.
}

antropoloji tarihini kolonyalizmden ayrı düşünmenin mümkün olmadığını belirterek başlamak gerekir. Çünkü uygulamalı antropolojinin ortaya çıkışı da kolonyalizme ilişik bu tarihin bir parçasıdır. Buna göre uygulamalı antropoloji 19. yüzyılda doğrudan kolonyalizm ile bağlantılı olarak ortaya çıkar. Dönemin uygulamalı antropologları olarak ele alınanlar Britanya İmparatorluğu'nun araştırmacılarıdır ve bu araştırmacılar imparatorluğa kolonileri hakkında bilgilendirici raporlar hazırlamakla görevlidirler (Rylko-Bauer, vd., 2006, s. 179). Bu dönemde zaten antropolojik bilginin yaygin bir biçimde kolonyal yönetime raporlar hazırlamak hatta bu yönetimi meşrulaştırmak veya gizlemek amacı ile üretildiğini düşündüğümüzde hemen şu soru akla gelebilir: Bu pratikler neden uygulamalı antropolojinin ilk örnekleri olarak ele alınır? Kolonyalizm yayıldığı coğrafyalardaki yerleşik hayatın her yönüne sirayet etmiştir. Örneğin kolonyal yönetimin izlediği ekonomiüretim ve bunları destekleyen arazi politikaları hâlihazırdaki toprak rejimini değiştirerek arazi kullanımında ihtilafların ortaya çıkmasına neden olur. Arazi kullanımdaki bu anlaşmazlıkların giderilmesinde antropologlara $\mathrm{da}$ iş düşer. Anlaşmazlıkların giderilmesinde kolonyal yönetimin başvuracağı, başka bir ifadeyle kullanacağ1 "uzman görüşü" (RylkoBauer, vd., 2006, s. 180) antropologların hazırladığ1 bilgilendirici raporlara dayanır. Baştaki sorunun cevabı da buradadir. Bilgilendirici raporlar ile temsil edilen antropolojik bilgi, uzman görüşü ile birleşerek dönemin toplumsal sorunlarının çözümünde etkili olur, işte bu sebeple de uygulamalı antropolojinin ilk örnekleri olarak ele alınmaktadır (Rylko-Bauer, vd., 2006, s. 179-180).

Uygulamalı antropolojinin gelişimindeki bir diğer önemli durak ise bir sonraki yüzyılın ilk yarısıdır. 20 . yüzyılın ilk yarısını bu bağlamda önemli kılan savaşlardır ve uygulamalı antropoloji de bu kez savaşlar ile ilgisinde sahadadır (Maida ve Beck, 2015, s. 13-14; Rylko-Bauer, vd., 2006, s. 181). Özellikle de II. Dünya Savaş1 ve Pasifik Cephesi, Amerikan Antropolojisi içindeki toplumsal sorunların çözümüne etki edecek uygulama meselesinin yöneldiği temel odağ1 oluşturur. Savaşın seyrinde ve oluşturduğu sorunlarda karşılığını bulacak bir etki yaratma amaciyla kimi antropologlar askeri propaganda oluşturulmasinda kimileri de istihbarat servislerinde çalışır (Price, 1998, s. 379-380; Maida ve Beck, 2015, s. 13-14). Bunların yanı sıra "topluluk analisti” (Rylko-Bauer, vd., 2006, s. 181) olarak çalışan antropologlar da vardır. Rylko-Bauer ve diğerleri (2006, s. 181) "topluluk analisti” ifadesini II. Dünya Savaşı boyunca Amerikan toplumuna entegre edilmeleri amacıyla Amerika'da yaşayan Japonların toplandıkları kamplarda çalışan antropologlar için kullanırlar. Bu antropologlar çalışmaları aracılığıyla kampların daha iyi, başka bir deyişle amacına uygun bir biçimde işlemesine 
katkıda bulunurlar. Bahsedilen bu çalışmalar da yine döneminin toplumsal sorunlarının çözümüne yönelik olmalarıyla uygulamalı antropoloji içinde değerlendirilir ve bu yaklaşımın gelişimi temsil eden örnekler olarak gösterilir. Ancak bu pratikler arasında daha yakından bakıldığında oldukça önemli bir başka ortak özelliğin daha olduğu görülebilir. Bu ikinci ortak özelliği açığa çıkarmak için de "sorun" ve "çözüm” olarak addedilenin üzerinde durmak gerekir.

Uygulamalı antropolojinin bu ilk örneklerinde bakıldığında sorun olarak kabul edilenlerde ve bunların çözümünde iktidarı görmek mümkündür. Genelde olduğu gibi burada da sorunun ne olduğunu belirleyen iktidardır. Çözüm de yine iktidar politikaları ve stratejileri içinden, bu politika ve stratejilerle uyumlu bir biçimde yürürlüğe konur. Bir başka deyişle çözüm, mevcut sistem nezdinde makbul, mevcut sistemin meşruluğunu ve devamlılığını korumayı hedefleyen uygulamalardır. Buna göre uygulamalı antropoloji tarihinin erken örneklerini temsil eden bu çalışmaların ayrıca iktidar ile kurulan ilişkide de ortaklaştıklarını söylemek gerekir. Uygulamalı antropoloji siyasal iktidardan yana konum alıp bu konumdan hareketle "mevcut toplumsal düzeni sürdürmeye yönelik" (Baykal Büyüksaraç, 2019, s. 72) bilgi üreterek toplumsal sorunların çözümünde çalışmak üzere ortaya ç1kmış ve gelişmiştir. Elbette ki 19. yüzyıldan itibaren iktidar ile kurulan bu ilişkinin dişında yer alan, Lyon ve Hyatt'ın (2003, s. 177-179) "aşağıdan etnografi (ethnography from below)" diye adlandirdiklar1 yaklaşım içinden yürütülen çözüm odaklı antropolojik çalışmalardan da söz edilebilir. Bu çalışmalar, örneğin eşitsizlik, 1rkçılık gibi sorunlar karşısında eşitsiz, 1rkçı uygulamalara maruz kalanlarla birlikte çalışarak bu kişilerin ya da grupların hayatlarında olduğu kadar bu uygulamaları üreten, devamlılığını sağlayan iktidar sistemlerinde de bir dönüşüm yaratmay1 hedefleyen çalışmalardır. Yerli halkları koruma amacıyla kurulan hak temelli derneklerde ${ }^{5}$ çalışan veyahut yoksulların barınma hakkı için mücadele veren antropologların ${ }^{6}$ ortaya koydukları, bu çalışmalara ait örneklerden bazılarını oluşturur. Irkçılık karşıtı mücadelesiyle Boas da burada anılması gereken bir başka antropologdur (Checker vd., 2010, s. 5; Fassin, 2013, s. 625). Ancak değinilen bu çalışmalar politik bir mücadele alanına ait, "aktivist" pratikler diye değerlendirilir dolayısıyla da hem uygulamalı antropolojinin hem genel olarak disiplininin ve tarihinin dişında birakılır (Maida ve Beck, 2015, s. 9).

Uygulamalı antropoloji ise, toplumsal sorunların

\footnotetext{
${ }^{5}$ Aboriginal Protection Society (1838). Ayrıntılı bilgi için bkz. Maida ve Beck, 2015, s. 9.

${ }^{6}$ Woman's Anthropological Society (1883). Ayrıntılı bilgi için bkz. Maida ve Beck, 2015, s. 9.
}

çözümüne iktidarın bakış açısından odaklanan bir yaklaşım olarak, antropoloji ile aktivizm arasındaki temel ayrımın belirlediği sınırlar içinde gelişmeye devam eder. Yine de bu uygulamalı araştırmacılık, Baykal Büyüksaraç'in (2019, s. 74) da ifade ettiği gibi, teorik kazanımlarını arttıran bilimsel-akademik camianın eleştirilerinin hedefindedir. Eleştiriler uygulamalı antropolojinin aldığı konuma, sonuçlarına yani genel olarak etiği ve politiğine yönelik değildir. Aslına bakılırsa iktidarın sorgulanması, iktidar süreçlerinin incelenmesi meselesi, henüz genel olarak antropolojinin gündeminde değildir. Dolayısıyla uygulamalı araştırmacılı̆̆a getirilen eleştiriler de teorik düşüncenin üstünlüğünden hareketle ve teorik düşünceye eklenecek yeni bilgiler üretilmesi gerekliliğinden türetilir. Meseleye buradan bakan bilimsel-akademik camia, pratik sonuçları hedefleyen uygulamalı antropolojiyi pek de makbul bulmamakta hatta küçümsemektedir. Uygulamalı antropolojinin bu camia tarafindan küçümsenmesine tepki olarak bir grup antropolog, 1941 yilinda Amerikan Antropoloji Derneği'nden (American Anthropological Association) ayrilarak Uygulamalı Antropoloji Derneği'ni (Society for Applied Anthropology) kurar (Lamphere, 2015, s. 162; Baykal Büyüksaraç, 2019, s. 174). Bu ayrılma iki ayrı alanın temsili haline gelir: Araştırma gündemlerini oluşturan konuları belirleyen, teori ve yöntemi üreten antropologlara ait akademi ile sivil toplum kuruluşları ve resmi kurumlar gibi akademi dışı ortaklar ile işbirliği içinde çalışan antropologlara ait uygulamalı alan (Mars, 2004, s. 1; Lamphere, 2015, s. 162-163). Birincinin ikinciye olan küçümseyici tavrı ile bu iki alanın varlı̆̆ı geçerliğini korumaya devam eder ${ }^{7}$. Günümüzde de uygulamalı antropoloji, belli sorunlara çözüm getirme amacıyla akademi dışı ortaklar ile işbirliğinde yürütülen daha çok proje bazlı araştırmaları ifade eder.

Uygulamalı antropoloji yaklaşımına getirilen eleştiriler şüphesiz ki öncesinde bahsedilenler ile sınırlı değildir, ancak eleştirilerin yoğun bir biçimde yöneltildiği noktanın akademi dışı ortaklıklar üzerinden ilerleyen proje bazlı araştırmalar yürütülmesi olduğunu söyleyebiliriz. Scheper-Nancy ve Bourgois'nın (2004, s. 8) da ifade ettikleri gibi, temel niteliklerinden olan ortaklıklar üzerinden çalışmalar planlanması ve yürütülmesi uygulamalı antropolojiyi neoliberal düzenin piyasa odaklı araştırmalarından biri haline getirir. Ayrıca, hangi ortaklarla işbirliği yapıldığı, ortaya çıkan bilginin kimlerle ve hangi amaçla paylaşılacağ1, bu bilgiden kimlerin ne yönde faydalanacağ1 gibi ikircikli meseleler

\footnotetext{
${ }^{7}$ Üniversiteler ile özel sektör işbirliğini destekleyerek proje ve piyasa odaklı profesyonelleşmeyi teşvik eden yükseköğretim politikaları bu ayrımı zorunlu bir biçimde ortadan kaldırmaya yönelik bir etken olarak tartışılmalıdır.
} 
de uygulamalı antropolojiye yöneltilen eleştirilerin temelinde yer alır. Aslında bu eleştirileri, disiplinde de köklü değişimler yaratan 1960’lı yllardan itibaren dünyanin hem siyasal-toplumsal düzlemde hem de bununla bağlantısında düşünsel-epistemolojik düzlemde yaşadığı dönüşüm ile ilgisinde değerlendirmek gerekir. $\mathrm{Bu}$ dönüşüm antropolojide de iktidar, farklı iktidar ilişkileri, bu ilişkiler içinde bilginin inşası gibi meselelerin ele alınmasını ve beraberindeki çok boyutlu sorgulamayı harekete geçirir. Aktivist antropoloji de bu dönüşümün bir parçası aynı zamanda disiplindeki sorgulamanın hem kurucularından hem de sonuçlarından biri olarak ortaya çıkar.

\section{Toplumsal sorunların birlikte mücadelede antropoloji \\ çözümüne yönelik çalışmak: Aktivist}

20. yüzyılın ikinci yarısında dünyayı sekillendiren mevcut siyasal, toplumsal ve düşünsel sistemler oldukça güçlü eleştirilerin hedefindedir çünkü bu dönem, "pek çok siyasi deneyimin travmatik mirasını taşımaktadır" (Braidotti, 2018, s. 29). Dünya savaşları, özellikle de II. Dünya Savaşı bu eleştirileri harekete geçiren unsurların en başında gelir. Aynı zamanda sömürgeciliğin geri çekilişi, sömürge karşıtı özgürlük mücadeleleri ve bu mücadeleler ile daha geniş bir alanda duyulur hale gelen sömürge karşıtı sorgulamalar bu eleştirilere kaynaklık eden bir diğer unsurdur. Feminist hareketin güçlendirdiği yeni bakış açıları ile getirdiği sorgulamalar da başat unsurlardandır. $\mathrm{Bu}$ birbirinden beslenen unsurların harekete geçirdiği eleştiriler dünyanın artık mevcut siyasal, toplumsal sistemlerle düzenlenebilir, hâlihazırdaki düşünsel sistemler ile anlaşılabilir olmadığını açıkça ortaya koyar. Dönemin Avrupa ve Amerika kentleri savaş, 1rkçılık ve nükleer karşıtlığı, sivil haklar mücadelesi gibi hareketler tarafindan düzenlenen, caddeler boyunca uzanan kitlesel gösteri yürüyüşleri ile betimlenir (Kirsch, 2010, s. 69; Lamphere, 2015, s. 167). Böyle bir çerçevede 1960 ila 1970 yıllarının yeni arayışların dönemi olduğu söylenebilir. Braidotti'nin (2018, s. 29) sözleri ile yeniden ifade edecek olursak, bu dönemde yeni "toplumsal hareketler, radikal bir siyaset, toplumsal kuramlar ve yeni epistemolojiler" üretilir.

Yeni arayışları başlatan bu eleştiriler antropolojide de karşıllğını bulur. Öncelikli olarak disiplin ile kolonyalizm bağına odaklanılır. Araştırma nesnesinin, baştan sona araştırmanın ve bu yolla bilginin kurulmasında, bilginin kullanılmasinda antropoloji ile kolonyalizm arasındaki bağın kurucu olduğu ancak bu bağın görmezden gelinerek veya üzeri örtülerek hiç sorun edilmemiş olmasına yönelik oldukça kapsamlı bir tartışma başlar (Asad, 2008). Bu tartışmalar ile Siyah Antropologlar Derneği'nin (Association of Black. Anthropologists) kurulmas1 eşzamanlıdır. Harris'in (1987, s. 18) aktardığ gibi "Siyah ve kolonileştirilmiş antropologlar"ca 1973 yllında kurulan bu derneğin amac1 "kolonyalizmi ve 1 rkçıllı̆̆1 meşrulaştıran teoriler"i ayrıca "mevcut yaklaşım, yöntem [...] ve antropologlar ile araştırdıkları halklar arasındaki ilişkileri değiştirmektir”. Aynı zamanlarda yayımlanan Barbados Bildirgesi de antropoloji ile kolonyalizm arasındaki bağ1 hedef alır. 1971'de "çoğunluğu Latin Amerikalı olan" bir grup antropolog "antropoloji ile yerli halklar arasındaki ilişkileri değerlendirmek" (Hale, 2006, s. 99) için bir araya gelir. Bu buluşmanın sonucunda Hale'in (2006, s. 99) Walter Dostal'dan aktardığı üzere, antropolojinin bilimsel bir dil kullanarak tahakkümü rasyonel ve meşru kıldığını ancak bunun yerine sömürge özgürlük mücadelesine katkı sağlayacak bilgi ve yorum üreten bir antropolojinin tesis edilmesi gerektiğini ifade eden Barbados Bildirgesi yayımlanır ${ }^{8}$. Hem Siyah Antropologlar Derneği hem de Barbados Bildirgesi antropolojiyi politik bir mücadele ile ilișkilendiren yeni bir bakışı ve konumu temsil eder. Öncekilerden farklı olarak bu radikal bakış ve konum sadece göz ardı edilen meseleleri odağa taşımakla kalmaz, aynı zamanda bir mücadele alanı olarak gördükleri antropoloji ile akademide de bir dönüşüm hedefler.

En başta antropoloji ile kolonyalizm arasındaki bağ1 merkeze alarak başlayan sorgulamalar zamanla çok katmanlı hale gelerek "antropoloğun bilgi kaynağ1 olan 'öteki' ile kurduğu ilişkiyi de” sorunsallaştırır (Kayaalp, 2014, s. 123). Bu ilişki sadece kolonyalizmin ön ayak olduğu asimetrik güçlerin karşılaşmasıyla sınırlı bir sonuç değildir, antropolog ile "kişileri" arasındaki doğrudan ilişki de hiyerarşik bir ilişkidir. Bu ilişkiyi, bu ilişki sonucu ortaya çıkan antropolojik temsil repertuarını da içerir biçimde genişleyen sorgulamalar nesnellik idealiyle pozitivist epistemolojiye yönelmiş mevcut eleştiriler ile birleşir. Şimdiye dek kabul edilen teori ve yöntemleri hedef alan, en çarpıcı örneklerini 1986'da Clifford ve Marcus'un yayımladıkları Kültürü Yarmak (Writing Culture) kitabında yer alan tartışmaların oluşturduğu antropolojiye dair yeni kavrayışlar, yaklaşımlar ortaya çıkar. Böylece antropoloji artık iktidarı, çeşitli iktidar ilişkilerini yansıtan süreçleri ayrıca bu ilişkiler içindeki eşitsiz uygulamalar gibi toplumsal sorunların incelenmesini, eleştirisini de içerir hale gelir. Ancak bu yeni kavrayış ve yaklaşımlar içinde oldukça önemli bir mesele görmezden gelinmiştir: toplumsal cinsiyet rejimi (Abu-Lughod, 1991, s. 137). Herhangi bir toplumsal gerçekliği toplumsal cinsiyet rejimini hesaba katmadan anlayabilmenin mümkün olmayacağını vurgularken, feminizm bir yandan da tahakküm ilişkilerini açığa çıkarıp yerleşik eşitsizlikleri hedef alan, bunları değiştirmeyi, iyileştirmeyi, daha yerinde bir ifadeyle y1kmayı

Antropolojide uygulama meselesini tartışırken Barbados Bildirgesi'nin daha kapsamlı bir değerlendirmesi için Hale'in (2006) yanı sıra bkz. Baykal Büyüksaraç, 2019. 
amaçlayan bir mücadeledir de. Araştıran ile katılımcılar arasında eşitlik temelinde bir ilişki kurulmasına azami dikkat gösteren feminist epistemoloji ve yönteme dayanan antropolojik çalışmalar da bir yandan çok katmanlı tahakküm ilişkilerini açığa çıkarmayı amaçlar, diğger yandan da araştırmacı ile araştırma öznelerinin ortaklaşa ürettikleri bilginin en azından her iki taraf için de bir güçlenmeye ve bilinç yükselmesine yol açmasını hedefler (Şentürk 2016, s. 69-70). Şentürk’ün (2016, s. 69) ifadeleriyle "feminist araştırmacı bir dokunuşuyla tahakküm ilişkilerini yerinden oynatamaz". Yine de feminist tavir, Siyah Antropologlar Derneği ile Barbados Bildirgesi gibi, bu ilişkiler ve bunların yarattı̆̆1 eşitsizliklerin kişilerin gündelik deneyimlerine nasıl yansıdığını anlamak, bu eşitsizlikleri incelenmek, eleştirisini ortaya koymak ile aynı zamanda bunları düzeltmek için çalışmak arasında önemli bir fark olduğunu gösterir. Ancak akademiye ait alan içinden antropoloji, düzeltmek için çalışmayı pek de makbul bulmaz. Aktivizm hala akademik bir etkinlik olarak bilgi üretmenin dışında görülürve aktivist araştırma yürütenler de bilimsel-akademik camianın dışına itilir (Hale, 2018, s. 3). Aktivist kimliğinin araştırmacı kimliğini gölgede b1rakacağ1 nedeniyle aktivist bir antropoloğun "gerekli profesyonel mesafeden yoksun” (Clifford, 1997, s. 212) olacağ1 kabul edilir. Bunun sonuncunda üretilen bilginin analitik, teorik düşünceden uzak yani antropolojik sayılamayacağ1 öne sürülür (Scheper-Hughes, 1995, s. 418; Baykal Büyüksaraç, 2019, s. 78). Aktivizm ile olan dışlayıcı ilişkisi güçlü bir biçimde devam etse de antropolojinin aktivizme kapıyı araladığı (yöntemsel) bir yer vardır. O yer de "çok-alanlı etnografi" dir (Marcus, 2015).

Öncesinde de ifade edildiği gibi, özellikle de 1980’lerden itibaren iktidar ve değișen ekonomi politik sistemlerin, kisaca dünya sistemi diye adlandirılan makro süreçlerin öznelerin yaşamlarını şekillendirdiği, kültürlerin bileşenlerinden biri olduğu yayg1n bir biçimde kabul görür hale gelmiştir (Marcus ve Fischer, 2013, s. 125-131). Ancak yerel bilgiye odaklanagelen antropolojinin bu makro süreçleri etnografilere nasil yansıtacağ1 günümüzde de süren tartışmaların konusudur (Marcus ve Fischer, 2013, s. 141). Marcus (2015), hem yerel bilgiyi hem de makro süreçleri içeren dünya sisteminin etnografisi olarak "çok-alanlı etnografi"yi önerir. Birbiriyle bağlantılı pek çok ilişkiyi bir araya getirmeyi amaçlayan çok-alanlı etnografide Marcus, alanlar arasında "hareket etme[nin] [...] araştırmaya bir aktivizm özelliği”" (2015, s. 406) kattı̆̆ını söyler. Ancak bu aktivizm, "akademi ya da araştırma uzmanlığı dışında belirli bir sosyal hareketle ortaklik noktası talep edilen bir aktivizm [...] değildir [.] Daha ziyade bu çok-mevkili [çok-alanlı] araştırma yapmanın koşullarına özgü ve dolaylı bir aktivizmdir" (Marcus, 2015, s. 406). Başka bir deyişle Marcus'un "dolaylı aktivist olarak etnograf" (2015, s. 406) diye adlandırdığ1, dünya sistemine ilişkin bilgi edinmeye çalışan antropoloğun farklı alanlar içinde edindiği araştırmacı konumlarından sadece biridir. Buna göre aktivizm içinden üretilen bilginin hangi koşullar altında antropolojik bilgi sayılacağı da tanımlanmış olur. Araştırmanın başında itibaren etnograf olarak kalmak esastır. Ancak araştırmanın seyri, bu esas konumu yerinden etmeksizin aktivist bir konum benimsemeyi de gerektirebilir. İşte, ancak böyle durumda aktivizm dolayımla üretilen bilgi antropolojik bilgidir. 1960 ve 1970'li yilların toplumsal hareketler ve siyaset biçimlerinin yeni kuram ve epistemolojilerle birleşerek oluşturduğu radikal dönemeçte gelişen aktivist antropoloji ise, toplumsal sorunların ele alınması meselesinde sınır bildiren kuramsal seti kırmaya yöneliktir. Aktivist antropoloji, birbirini dişlayan veya zorunlu, dolaylı bir ilişkiden ziyade disiplin ile mevcut sorunlar arasında pratik bir bağlantı kurarak aktivizm ile antropolojiyi bir araya getirir. Yazının devamında da örneklerle aktivist antropolojiye odaklanılmaktadir.

Disiplinde yaşanan sorgulamalar ile birlikte etnografik araştırmanın öznel bir doğası olduğu çokça tartışıldı, üzerine çokça yazıldı. Araştırmacının kişisel tarihi, sınıfı, cinsiyeti, eğitimi, ilgi alanları gibi birçok özellik konu seçiminden başlayarak araştırmanın seyrine etki eden unsurladır. Aktivist bir araştırma da bu öznel doğanın dişında değildir', araştırmacı yine kendi deneyimlerinden hareketle bir konuya odaklanır, ancak burada farklı olarak politik bir bağlılık esastır. Bu politik bağlılık, örneğin ekolojik yıkım, iklim krizi, eşitsizlik, adaletsizlik gibi sorunları hedef alarak bunların çözümde etkili olmak, daha başka bir ifade ile bunları dönüştürmek, düzeltmek için verilen mücadelenin içinde olmak anlamına gelir. İşte bu politik bağlılık, en başından sona, hatta yayımlanma ve paylaşma aşamalarını da içine alacak bir biçimde araştırmanın yapisinı belirleyerek aktivist antropolojiye karakterini veren temel özelliklerden biri olarak karşımıza çıkar. Doğrudan bir mücadelenin içinde konumlanarak bir taraf olma ile başlayan araştırma, araștırma özneleri ile "başka yollardansa belli bir biçimde yaşama veya eylemde bulunmaya dair ortak anlaşmanın temelde

\footnotetext{
${ }^{9}$ Aktivist bir araştırmayı analiz ederken içinden çıkamadığım, nasıl ifade edeceğimi bilemediğim yerlerde Müge Tuzcuoğlu'nun kendi alan deneyimleri üzerinden verdiği örnekler, ortaya koyduğu tartışmalar oldukça yol gösterici oldu. Katkılarından dolayı Müge Tuzcuoğlu'na teşekkür ederim. Bu yazıda ele alınan tartışmaların alanda nasıl karşılık bulduğuna dair Türkiye antropolojisinden örnekler için bkz. Tuzcuoğlu, M. (2011). Ben bir taşım. Evrensel Basım Yayın. ve Tuzcuoğlu, M. (2014). Istenmeyen çocuklar: Roboski katliamını hatırlamak ve hatırlatmak. İletişim Yayınları.
} 
olduğu" (Besteman, 2013, s. 3) işbirliğinde devam eder. Aynı amaç etrafinda politik olarak konumlanmış öznelerin bu işbirliğine Scheper-Hughes (1995, s. 411) "yoldaşl1k" der. Bu, hem özneler arasındaki yatay ilişkiye vurgu yapar hem de antropoloğun sahadaki araştırmac1 konumları hakkında ipucu verir. Yazının daha önceki sayfalarında değinildiği gibi, antropolog ile araştırma özneleri arasındaki değişken, çoklu karşılıklı ilişkiler temelinde kurulan etnografik araştırma, antropoloğun bu ilişkiler içinde müzakere edilen konumları ile ilgilidir, bu konumlar içinden şekillenir. Amerika'nın Missouri eyaletinde yer alan Ferguson şehrinde 2014 yllinda, Siyah bir genç olan Michael Brown polis tarafindan vurularak öldürüldü. Michael Brown'un ölümü Ferguson ayaklanmasının fitilini ateşledi. Parikh ve Kwon, Ferguson ayaklanmasını odağa taşıyarak "henüz tamamlanmamış olan antropolojiyi sömürgecilikten arındırma meselesi"ni (2020, s. 116) tartıştıkları yazıda araştırmacı konumlarına da değinirler. Hâlihazırda bir parçası oldukları ırkçılık karşıtı mücadele ile Ferguson ayaklanmasina öncelikli olarak etnograf konumundan doğru katılmadıklarını ifade ederler. Bunun yerine, Parikh ve Kwon (2020, s. 112) ayaklanmaya annebaba, eğitimci, kurul üyesi gibi çeşitli konumlardan hareketle hem katıldıklarını hem de bir araya gelme, düzeltme, yüzyıllardır süren 1rkç1lık temelli eşitsizliği tasfiye etme çabalarını ve Siyah direnişinin yükselişini gözlemlediklerini ifade eder. Benzer bir tartısma, Vargas'in (2008, s. 164) Siyah karşıtı 1 rkçıllık ve sosyal adalet için mücadele eden derneklerle birlikte çalışmasından hareketle aktivist araştırmanın etnografik çalışmalar hakkındaki kabullerimizi, akademik bakış açımızı nasıl değiştirebileceğini ele aldığı yazısında da yer alır. Bahsedilen her iki çalışma da, araştırmacı konumlarının politik bağlllık içinden belirlendiğini anlatilir.

Aktivist antropolojiyi konu edinen daha birçok çalışmada araştırmacı konumlarının ele alındığı görülebilir. Bunlardan biri de kapitalizm karşıtı Küresel Direniş Hareketi'nde bir aktivist ve bir araştırmac1 olarak yer alan Jeffrey S. Juris'in (2007, s. 164-165) çalışmasıdır. Juris (2007, s. 165-166), aynı zamanda Vargas'ın (2008, s. 175-176) çalışmasında da olduğu gibi, araştırma konumlarını bir adım daha öteye taşır ve aktivist olmanın esas olduğu araştırma konumlarının biraradalı̆̆1 ile şekillenen yoldaşlık ilişkisinin bilgi üretme sürecine etkisini de ele alır. Bilimsel-akademik camiaya göre antropoloğun profesyonel mesafeden yoksun dolasıyla analitik-teorik yaklaşımdan uzak olması ile malul olan aktivist araştırma Juris ve Vagnas'a göre aksine, çok daha derin bir yorumlamayı, analizi mümkün hale getirir. Aktivist araştırma antropoloğu “tanıklik etmenin" (Scheper-Hughes, 1995, s. 419) ötesine taşır. Mücadele içinde olmak, o mücadele içinde yer alanlarla birlikte çalışmak antropoloğun çok daha bir aktif bir katılımla ${ }^{10}$ sahanın içine dalmasını sağlar (Juris, 2007, s. 165-166; Vargas, 2008, s. 175-176). Juris bunu, Schepher-Hughes'in Brezilya'nin yoksul gecekondu yerleşimlerindeki gündelik şiddete ilişkin çalışmasında kullandığ 1 ifadeleri aktararak anlatır:

Ama daha fazlası, yoldaşlarım tatlı sert bir biçimde beni, kendimi en rahat hissettiğim gecekondu mahallesinin kötü durumdaki kulübelerinin 'özel' dünyasından, topluluk hakkındaki anlayışımı zenginleştiren ve teorik ufkumu genişleten Bom Jesus da Mata'nın 'kamusal' dünyasına, piyasaya, belediye başkanlığına, morglara, fabrikalara ve kırsal toplantılara doğru çekip çıkardılar. (ScheperHughes, 1995, s. 411 akt. Juris, 2007, s. 166)

Yoldaşlı̆̆ın getirdiği bu çok daha aktif kattlım, Scheper-Hughes'in bu ifadelerinden de anlayabileceğimiz üzere, birbiriyle kesişen karmaşı ilişkileri bir araya getirerek antropoloğun çok boyutlu bir bakış açısı edinmesini sağlar. Bu yolla üretilen bilgi de kolektif bilgi olacaktır. Aktivist antropolojide sadece araştırma anı değil, araştırma sonrası da kolektiftir. Bilginin nasıl kullanılacağı, nasıl anlatılacağı, kimlerle, ne yolla paylaşılacağı gibi daha çok yazma, yayınlama gibi araştırma sonrası olarak görülen aşamalar da öznelerle birlikte şekillenir. Araştırmanın en başından itibaren kolektif olması ayrıca bilginin, temsil biçimi ile olduğu kadar kimlerle, nasıl paylaşılacağına dair de doğrudan araştırma öznelerine duyulan sorumluluk ile şekillenir. Ayrıca, antropolojide süregide bir tartışma olan temsil meselesine dair de bir açılımdır bu. "[B]aşkalarını temsilen söz söyleme ve harekete geçme girişimi" (Büyüksaraç, 2019, s. 80) değil, aktif bir katılımın sağlandığı kolektiviteler içinden sözü birlikte üretme ve bunu dile getirme esastır. Bu da meselenin adına/ hakkında konuşma tuzağına düşmeden aktarılmasının önünü açar.

Üretilen, birlikte şekillendirilerek ortaya konan bu kolektif bilgiyle hedeflenen politik mücadelenin hedefindeki sorunların ortadan kaldırılmasına yönelik pratik sonuçlar elde etmek, en azından bu mücadeleyi

\footnotetext{
${ }^{10}$ Parikh ve Kwon (2020, s. 112) ile Vargas (2018, s. 165; 175-176), aktivist araştırmanın antropoloğu aktif bir katılımcı kılmasını ifade etmek için gözlemci katılım (observant participation)" kavramını kullanırlar. Gözlemci katılım, gözlemden ziyade katılımın esas olduğunu vurgulamaktadır.
} 
güçlendirmek adına kamusal bir sorumluluk ile kamusal bir ses oluşturmaktır. Amaçlananın sadece bununla sınırlı olduğunu söylemek aktivist antropolojinin akademi ile olan ilişkisini gözden kaçırmaya neden olur. Hatırlamak gerekirse, aktivist antropoloji, aktivizm ile antropoloji arasındaki mesafeyi ortadan kaldırmayı da hedefler.

Aktivist antropoloji, mevcut sorunları dile getiren bir rapor ve sorunların çözümü için bu raporun seslendirilmesi biçiminde akademik çalışmayı önemsizleştiren veya zayıflatan bir çabanın, çalışmanın ifadesi olarak düşünülmemelidir. Aktivist antropoloji, araştırma öznelerine olduğu kadar akademiye karşı da sorumludur. Aktivist antropolojinin akademiye olan sorumluluğu, kolektif bilgiyi teorik ve kuramsal tartışmalar ile ele alarak hem etnografik yöntem ile antropolojiyi daha eşitlikçi, daha adaletli bir dünya kurma imkânına dâhil etme hem de hâlihazırdaki akademik düşünüş ve tavırda dönüşüm yaratma çabasıdır. Disiplini de bir mücadele alanı olarak gören aktivist antropoloji, antropolojinin bir alanı değil, antropolojik bir pratik ve ifade biçimidir (Checker, vd. 2010, s. 5-6). Bu pratik ve ifade ediş biçimiyle yerleşik akademik kuramsal setlere, bu setlerle çizilen sınırlara karşı da bir mücadeleyi ifade eder (Scheper-Hughes, 1999, s. 420).

\section{Sonuç yerine}

Eşitsizliğin, adaletsizliğin gündelik deneyimin bir parçası haline geldiği, ekolojik y1kımın, iklim krizinin etkilerinin apaçık hissedildiği bir dünyayı nasıldönüştürebileceğimizi sormamız, bunun yollarını yaratmayı aramak etik bir zorunluluktur. $\mathrm{Bu}$ yazı da, benimsediği etnografik yöntem ile antropolojinin bu dönüşüme katk1 sunabileceği iddiası üzerine temellenmiştir. Yazı, bu iddia ile ilgisinde "neden antropoloji" sorusunu gündeme taş1yarak, bu soruya aktivist antropoloji içinden cevaplar vermeye çalışmıştır. Yazı boyunca aktivist antropoloji, mevcut toplumsal sorunlar karşısında pratik sonuçlar elde etmeye yönelik politik bir mücadele içinden bilgi ve söylem üretmeyi hedefleyen antropolojik bir pratik ve ifade biçimi olarak ele alınmıştır. Yazıya öncelikli olarak antropolojik bir norm olarak karşımıza çıkan antropoloji ile aktivizm arasındaki temel yarılmayla başlanmıştır. Bu yarılma, örneklerden hareket edilerek ortaya konmaya çalışılmıştır. Bu yolla ayrıca, aktivist antropolojiye dair tartışmanın çerçevesini oluşturan tarihsel ve bilgisel bağlamın bileşenlerini ele almak için bir zemin oluşturulmuştur. Antropoloji ile toplumsal sorunlar karşısında pratik sonuçlar elde etmeye yönelik bir yaklaşım bir araya gelir gelmez, akıllara da hemen uygulamalı antropoloji gelir. Uygulamalı antropolojinin ele alınmasında disiplin tarihiyle eş zamanlı bir soruşturma izlenerek, sorun ve çözüm olarak kabul edilenlerin mercek altına alınmasiyla antropoloji ve iktidar arasındaki ilişki sorunsallaştırılmıştır. Ardından bu ilişkinin disiplin içinde sorgulanmasını harekete geçiren tarihsel, toplumsal, bilgisel değişimlere değinerek aktivist antropolojinin ortaya çıktı̆̆1 çerçeve ortaya konmaya çalışılmıştır. Bu yolla aktivist antropolojiye dair tartışma hem analitik bir yaklaşım ile geniş bir tarihsel ve bilgisel bağlam içinden kurulmuş hem de izlenen her adımda aktivist antropolojinin özgünlüğüne ilişkin ipuçlarının açı̆̆a çıkarılmasına çalışılmıştır. Nihayet, aktivist antropolojinin araştırma öncesinde, anında ve sonrasında nasıl bir yol izlediği ele alınmıştır.

Ancak burada aktivist antropolojinin özelliklerinin ortaya konması, neyin aktivist antropoloji olduğunu tayin etmeye yönelik bir şablon çıkarmaya veya sabit bir dizi nitelikler listesiyle bir kategori oluşturmaya çalışmak değildir. Bu yazı ile hedeflenen, antropolojinin dünyayı daha iyiye doğru dönüştürmeyi hedefleyen mücadelenin bir parçası olabileceğini aktivist antropoloji aracılı̆̆ıyla ortaya koymaktır. Aynı zamanda yazıda aktivist antropolojinin yerleşik akademik ikiliklerin de ötesine geçme imkânı yaratan alternatif bir pratik ve ifade biçimi olduğu da gösterilmeye çalışılmıştır. Elbette ki aktivist araştırma, bir anda büyük dönüşümler yaratmayacaktır. Ancak önemli olan bu dönüşüm için mücadele etmek, bu mücadelede birlikte çalışmak ve akademik-bilimsel bilgiyi de bu amaçla kullanmaktır. David Graeber'in (2012, s. 15) de dediği gibi, "[b]elki de böyle bir dünyanın mümkün olmadı̆̆ı ortaya çıkabilir”.

\section{Kaynakça}

Abu-Lughod, L. (1991). Writing against culture. R. G. Fox (Ed.) içinde, Recapturing anthropology, working in the present (s. 137-162). School of American Research Press.

Akgül, U. (2013). Uygulamalı antropolojinin tarihine genel bir bakış. Antropoloji, (25), 67-87. https://doi.org/10.1501/ antro 0000000030

Asad, T. (2008). Giriş. T. Asad (Ed.) içinde, Antropoloji ve sömürgecilik. A. Karınca (Çev.) (s. 7-21). Ütopya Yayınevi.

Baykal Büyüksaraç, G. (2019). Araştırma yoluyla etki yaratmak: Antropolojik bilgi ve uygulama meselesi. Eğitim Bilim Toplum Dergisi, (17), 71-91.

Besteman, C. (2013). Three reflections on public anthropology. Anthropology Today, 29(6), 3-6. https://doi.org/10.1111/1467-8322.12069

Bora, T. (2 Aralık 2020). Aktivizm. Birikim. https://birikimdergisi. com/haftalik/10371/aktivizm

Braidotti, R. (2014). Insan sonrası. Ö. Karakaş (Çev.). Kolektif Kitap.

Checker, M., Vine, D., ve Wali, A. (2010). A sea change in anthropology? Public anthropology reviews. American Anthropologist, 112(1), 5-6. https://doi.org/10.1111/j.1548-1433.2009.01192.x

Clifford, J. (1997). Spatial practices: Fieldwork, travel, and the disciplining of anthropology. A. Gupta ve J. Ferguson (Ed.) içinde, Anthropological locations: Boundaries and grounds of a field science (s. 185-222). University of California Press. 
Clifford, J., ve Marcus, G. E. (1986). Writing cultures: The poetics and politics of ethnography. University of California Press.

Erdoğan, E. (2020). Suçluyum, çaresizim, kızgın ve kırgınım: Feminist sahanın duyguları, gücü ve etiği. E. Erdoğan ve N. Gündoğdu (Ed.) içinde, Türkiye'de feminist yöntem (s. 278-306). Metis Yayınları.

Eriksen, T. H. (2015). What everybody should know about natureculture: Anthropology in public sphere and 'the two cultures'. S. Beck and C. A. Maida (Eds.) içinde, Public anthropology in a borderless world (s. 264-285). Berghahn Books. https://doi. org/10.2307/j.ctt9qdb3w.15

Fassin, D. (2013). Why anthropology matters: On anthropology and its public. Cultural Anthropology, 28(4), 621-646. https:// doi.org/10.1111/cuan.12030

Geertz, C. (2010). Kültürlerin yorumlanması. H. Gür (Çev.). Dost Kitabevi.

Graeber, D. (2012). Anarşist bir antropolojiden parçalar. B. KurtegeSefer (Çev.). Boğaziçi Üniversitesi Yayınevi.

Hale, C. R. (2006). Activist research v. cultural critique: Indigenous land rights and contradictions of politically engaged anthropology. Cultural Anthropology, 21(1), 96-120. https:// doi.org/10.1525/can.2006.21.1.96

Hale, C. R. (2018). Introduction. C. R. Hale (Ed.) içinde, Engaging contradictions: Theory, politics, and methods of activist scholarship (s. 1-30). University of California Press. https://doi. org/10.1525/9780520916173-004

Harris, I. E. (1987). The association of Black anthropologists: A brief history. Anthropology Today, 3(1), 17-21. https://doi. org/10.1111/j.1548-7466.2010.01088.x

Juris, J. S. (2017). Practicing militant ethnography with the movement for global resistance in Barcelona. S. Shukaitis, D. Graeber ve E. Biddle (Ed.) içinde, Constituent imagination (s. 164-178). Ak Press.

Kayaalp, E. (2014). Etnografik çalışmalarda yeni arayışlar, alanlar ve failler. R. Aras (Ed.) içinde, Sinırları asmak: Türkiye'de sosyokültürel antropoloji ve disiplinlerarası yaklaşımlar (s. 123-144). Çizgi Kitabevi.

Kirsch, S. (2010). Expirements in engaged anthropology. Collaborative Anthropologies, 3, 69-80. https://doi.org/10.1353/ cla.2010.0001

Lamphere, L. (2015). Public anthropology and the transformation of anthropological research. S. Beck ve C. A. Maida (Ed.) içinde, Public anthropology in a borderless world (s. 162-191). Berghahn Books. https://doi.org/10.2307/j.ctt9qdb3w.11

Lyon-Callo, V., ve Hyatt, S. B. (2003). The neoliberal state and the depoliticization of poverty: Activist anthropology and "ethnography from below". Urban Anthropology and Studies of Cultural Systems and World Economic Development, 32(2), 175-204.

Maida, A. C., ve Beck, S. (2015). Introduction. S. Beck ve C. A. Maida (Ed.) içinde, Public anthropology in a borderless world (s. 1-35). Berghahn Books. https://doi.org/10.2307/j.ctt9qdb3w.5

Marcus, G. E. (2015). Dünya sistemi(nde/nin) etnografya(sı): Çok-mevkili etnografyanın ortaya çıkışı. N. S. Altuntek (Ed.) içinde, Yöntembilim üzerine antropolojike okumalar. E. Boz (Çev.), (s. 377-414). Dipnot Yayınları.

Marcus, G. E., ve Fischer, M. M. J. (2013). Kültürel elestiri olarak antropoloji: Insan bilimlerinde deneysel bir an. B. Cezar (Çev.). Koç Üniversitesi Yayınları.

Mars, G. (2004). Refocusing with applied anthropology. Anthropology Today, 20(1), 1-2. https://doi.org/10.1111/ j.0268-540X.2004.00244.x

Ortner, S. B. (1999). Introduction. S. B. Ortner (Ed.) içinde, The fate of "culture": Geertz. and beyond (s. 1-13). University of California Press.

Parikh, S., ve Kwon, J. B. (2020). Introduction: Still here in the afterlives. American Ethnologist, 47(2), 110-120. https://doi. org/10.1111/amet.12884

Price, H. D. (1998). Gregory Bateson and the OSS: World War II and Bateson's assessment of applied anthropology. Human Organization, 57(4), 379-384. https://doi.org/10.17730/ humo.57.4.7428246q71t7p 612

Rylko-Bauer, B., Singer, M., ve van Willingen, J. (2006). Reclaming applied anthropology: Its past, present, and future. American Anthropologist, 108(1), 178-190. https://doi.org/10.1525/ aa.2006.108.1.178

Scheper-Hughes, N. (1995). The primacy of the ethical: Propositions for a militant anthropology. Current Anthropology, 36(6), 409440. https://doi.org/10.1086/204378

Scheper-Hughes, N. (2009). Making anthropology public. Anthropology Today, 25(4), 1-3. https://doi.org/10.1111/ j.1467-8322.2009.00674.x

Scheper-Hughes, N., ve Bourgois, S. P. (2004). Introduction: Making sense of violence, N. Scheper-Hughes ve S. P. Bourgois (Ed.) içinde, Violence in war and peace: An anthology (s. 1-30). Blackwell Publishers.

Starn, O. (1986). Engineering internment: Anthropologist and the war relocation authority. American Ethnologist, 13(4), 700-720. https://doi.org/10.1525/ae.1986.13.4.02a00070

Stauder, J. (1974). The 'relavance' of anthropology to colonialism and imperialism. Race and Class, 16(1), 29-51. https://doi. org/10.1177/030639687401600102

Şenol Cantek, F., ve Zırh, B. C. (2014). Bir semt etnografisine doğru: Cebeci'ye bakmak. İdeal Kent, (11), 138-171.

Şentürk, B. (2016). Mahalle kahvesinde "abla”, kabul günlerinde "hanım": Sınıf ve toplumsal cinsiyet bağlamında gecekonduda kadın araştırmacı olmak. R. Harmanşah ve Z. N. Nahya (Ed.) içinde, Etnografike bikeâyeler Türkiye'de alan araştırması deneyimleri ( s. 68-85). Metis Yayınları.

Tuzcuoğlu, M. (2011). Ben bir taşım. Evrensel Basım Yayın.

Tuzcuoğlu, M. (2014). Istenmeyen çocuklar: Roboski katliamm batırlamak ve haturlatmak. İletișim Yayınları.

Vargas, J. H. C. (2008). Activist scholarship: Limits and possiblities in times of Black genocide. C. R. Hale (Ed.) içinde, Engaging contradictions: Theory, politics, and methods of activist scholarship (s. 164-182). University of California Press. 
Wacquant, L. (2014). Giriş. Bourdieu, P. ve Wacquant, L. (Ed.) içinde, Düşünümsel bir antropoloji için cevaplar. N. Ökten (Çev.) (s. 13-46). İletişim Yayınları.

\section{(c) (i) (8) \\ BY NC 2021. Telif haklar1 yazar(lar)a aittir}

Bu makale Creative Commons Atıf-GayriTicari 4.0 Uluslararası (CC BY-NC 4.0)

lisansının hüküm ve şartları altında yayımlanan açık erişimli bir makaledir. 